\title{
Molecular Detection of Some Virulence Genes of Staphylococcus aureus Isolates Associated with Bovine Mastitis in Arid and Semi-Arid Regions of India
}

\author{
Taruna Bhati $^{1 *}$, Kumar Gaurav², Sunita Choudhary², Diwakar ${ }^{3}$ \\ and Anil Kumar Kataria ${ }^{1}$ \\ ${ }^{1}$ Department of Veterinary Microbiology and Biotechnology, College of Veterinary and \\ Animal Science, RAJUVAS, Bikaner-334 001, Rajasthan, India \\ ${ }^{2}$ Department of Veterinary Microbiology, Aravali Veterinary College, Sikar, India \\ ${ }^{3}$ Center for Studies on Wildlife Management and Health, RAJUVAS, Bikaner, India \\ *Corresponding author
}

\section{A B S T R A C T}

\section{Keywords}

Bovine mastitis, Staphylococcus aureus, Hemolysins, Adhesins, Penicillin resistance

\section{Article Info}

Accepted:

22 October 2019

Available Online:

10 November 2019
Staphylococcus aureus (S. aureus) is one of the most common causes of contagious bovine mastitis and its different virulence factors involved in the pathogenesis are well documented worldwide. The present study was conducted in 107 isolates of S. aureus recovered from mastitic milk $(n=51)$, udder surfaces $(n=35)$ and milkers' hands $(n=21)$ for detection and characterization of genes encoding for hemolysins ( $h l a, h l b$ and $h l d$ ), leucocidin $(l u k-P V)$, surface proteins $(c l f \mathrm{~A}, c l f \mathrm{~B}, f n b \mathrm{~A}, f n b \mathrm{~B})$ and penicillin resistance (blaZ) by multiplex PCR. All the isolates were positive for blaZ, hla, hld and clfA genes while $94.4 \%, 85 \%, 63.6 \%, 44.9 \%$ and $19.6 \%$ isolates carried $c l f \mathrm{~B}, \mathrm{hlb}, \mathrm{fnbA}$, $f n b B$ and $l u k-\mathrm{PV}$ genes, respectively. Mastitic milk isolates showed higher frequency of $c l f \mathrm{~B}(96.07 \%)$ and $h l b(88.2 \%)$ genes, udder isolates for $f n b \mathrm{~B}(48.6 \%)$ and $l u k-P V$ $(42.9 \%)$ genes while isolates of human origin showed higher occurrence of fnbA $(66.7 \%)$ genes. An overall high prevalence of hemolysins, surface proteins, adhesins, and penicillin resistance genes was observed. A little association was seen between presence of hemolysin and blaZ genes and their phenotypic expression. The recovery of penicillin resistant $S$. aureus strains from bovine mastitis and close human contacts in India is of concern in clinical management of mastitis.

\section{Introduction}

Bovine mastitis is an economically important multi etiological disease and Staphylococcus aureus is the predominant contagious mastitogen in India (Gandhale et al., 2017) and worldwide (Hanon, 2017). The pathogenicity of $S$. aureus is related to the presence of wide variety of virulence factors enabling adherence, colonisation, invasion of 
the mammary cells, evasion of the immune defence mechanism and survival in the host environment (Memon et al., 2013).

The initial attachment of $S$. aureus to epithelial cells of the teat canal depends on the interaction of bacterial surface proteins called MSCRAMMs (microbial surface components recognizing adhesive matrix molecules), such as clumping factors $\mathrm{A}$ and $\mathrm{B}$ (clf $\mathrm{A}$ and $c l f \mathrm{~B})$ and fibronectin-binding proteins $\mathrm{A}$ and $\mathrm{B}$ $(f n b \mathrm{~A}$ and $f n b \mathrm{~B})$, with host fibrinogen and fibronectin proteins located in the basement membrane, around myoepithelial cells and fibroblasts (Ni Eidhin et al., 198; Wann et al., 2000). Staphylococcus aureus clfA and clfB and $f n b \mathrm{~A}$ and $f n b \mathrm{~B}$ proteins are also involved in the evasion of host immune responses due to their ability to bind fibrinogen on the $S$. aureus cell wall thereby inhibiting deposition of or access to opsonins to the pathogen (Higgins et al., 2006).

Staphylococcus aureus secretes several cytolytic toxins, among them are alpha, beta, and delta hemolysins and Panton-Valentine leukocidin (PVL). Cytolytic toxins form $\beta$ barrel pores in the plasma membrane and cause leakage of the cell's content and lysis of the target cell (Kaneko and Kamio, 2004).

Beta and alpha hemolysins are the most important in pathogenesis of the intramammarian infections (Park et al., 2004). The presence of PVL positive $S$. aureus strains from human and its clinical implications have been reported (Cirkovic et al., 2012) but scanty information is available about its presence in bovine mastitic milk and udders especially in India.

Although there are many reasons which compromise antibiotic treatment of $S$. aureus mastitis of which resistance of bacteria toward antibiotics is the most important one. Betalactam compounds such as penicillin continues to be one of the most frequently used drugs in veterinary medicine (Pitkala et al., 2007). Two primary resistance mechanisms to beta-lactams are there in Staphylococcus spp.: the expression of betalactamase enzymes encoded by the blaZ gene, and production of the penicillin-binding protein $2 \mathrm{a}$ (PBP2a) encoded by the mecA gene, which is coding resistance against almost all beta-lactam antibiotics which are widely used in mastitis treatment (Benic et al., 2012).

The strains of $S$. aureus have been reported to vary in pathogenicity due to diversion in expression of genes and showed differences in severity of mastitis (Haveri et al., 2007; Capurro et al., 2010).

Hence the present study was carried out for molecular detection of genes coding alpha, beta, and delta hemolysins and PantonValentine leukocidin (PVL), clumping factors $\mathrm{A}$ and $\mathrm{B}$ (clfA and $c l f \mathrm{~B})$, fibronectin-binding proteins $\mathrm{A}$ and $\mathrm{B}(f n b \mathrm{~A}$ and $f n b \mathrm{~B})$ and penicillin resistance (blaZ) in 107 S. aureus isolates from bovine mastitis and close human contacts in arid and semi-arid regions of India.

\section{Materials and Methods}

\section{Ethical approval}

This study was conducted following approval by the research committee and guidelines of Institutional animal ethics committee were followed.

\section{Isolation, identification and genotypic confirmation of $S$. aureus isolates}

A total number of $107 \mathrm{~S}$. aureus isolates comprising of 51 isolates from mastitic milk, 35 isolates from udder surface swabs and 21 from milkers' hands swabs collected from seven different farms in arid and semi-arid 
regions of Rajasthan, India were included in the study. The isolates were primarily identified by Gram staining, catalase test, coagulase test and fermentation of mannitol salt agar (Markey et al., 2013) and genotypically confirmed by $23 \mathrm{~S}$ rRNA gene based ribotyping (Straub et al., 1999) and nuc gene amplification as per Brakstad et al., (1992) as described earlier (Bhati et al., 2018).

\section{Hemolysins characterization}

The patterns of hemolysis by $S$. aureus isolates were examined by streaking on sheep blood agar plates and incubating at $37{ }^{\circ} \mathrm{C}$ for 24 h (Quinn et al., 2000).

The hemolysins were identified using following criteria: complete zone of hemolysis with unclear edges for $\alpha$-hemolysin and incomplete zone of hemolysis which after incubation at $4{ }^{\circ} \mathrm{C}$ overnight became complete with sharp edges, for beta hemolysin (Quinn et al., 2000; da Silva et al., 2005).

\section{Beta-lactamase activity (Acidimetric method)}

Hydrolysis of the $\beta$-lactam ring generates a carboxyl group, acidifying unbuffered systems. The resulting acidity can be tested in tubes by the method described by (Livermore and Brown, 2001) in which $2 \mathrm{ml}$ of $0.5 \%$ (w/v) aqueous phenol red solution was diluted with $16.6 \mathrm{ml}$ distilled water, and $1.2 \mathrm{~g}$ of benzylpenicillin was added to it.

The $\mathrm{pH}$ was adjusted to 8.5 with $1 \mathrm{M} \mathrm{NaOH}$ and $100 \mu \mathrm{l}$ of the resulting solution (violet in color) was distributed into microtitre wells and inoculated with bacteria from culture plates to produce dense suspensions.

Development of yellow colour within 5 min indicated $\beta$-lactamase activity. Positive and negative controls were run in parallel.

\section{Molecular detection of $S$. aureus virulence genes by PCR}

Bacterial culture was grown overnight and DNA was isolated (Nachimuttu et al., 2001) and DNA quantification was carried out by spectrophotometric measurements (Sambrook et al., 1989). Three sets of multiplex PCR were designed for genes having similar annealing temperatures with slight modifications: Set A for blaZ, fnbA and fnbB; Set B for $l u k-\mathrm{PV}, h l d$ and $c l f B$ genes and Set C for $c l f A$, $h l a$ and $h l b$. The PCR mixture for each set of multiplex PCR consisted of $5.0 \mu \mathrm{l}$ $5 \mathrm{X}$ Go Taq ${ }^{\circledR}$ Flexi buffer, $3.0 \mu \mathrm{MgCl}_{2}$ (25mM), $1.0 \mu \mathrm{l}$ dNTP mix (25mM each), 0.2 $\mu 1$ Taq DNA polymerase $(5 \mathrm{U} / \mu \mathrm{l}), 3.0 \mu \mathrm{l}$ DNA template $(30 \mathrm{ng} / \mu \mathrm{l})$, primers sequences and concentration as described in Table 1 and nuclease free water to make a total volume of $25 \mu 1$. Amplification was carried out in a Veriti thermal cycler (Applied biosystem) using protocol as mentioned in Table 2. Amplified PCR products $(5 \mu \mathrm{L})$ were separated by electrophoresis in $1.2 \%$ agarose gel stained by ethidium bromide and visualized under a UV transilluminator (ENDURO GDS).

\section{Results and Discussion}

In the present study an overall recovery rate of $S$. aureus was $54.3 \%$ with highest prevalence of $63.8 \%$ in mastitic milk samples followed by $53 \%$ (udder surface) and 41.2\% (milkers' hands), as described earlier (Bhati et al., 2018). Of the 107 isolates, five $(4.7 \%)$ isolates produced complete (alpha) haemolysis, 58 (54.2\%) produced partial (beta) haemolysis and three $(2.8 \%)$ exhibited both complete and partial hemolysis on blood agar. When plates with partial haemolysis were subjected to further incubation at $4^{\circ} \mathrm{C}, 54$ isolates $(93.1 \%)$ showed turning of partial hemolysis to complete hemolysis (hot-cold lysis) whereas other four isolates $(6.9 \%)$ did not show hotcold lysis. Hence a total of $66(61.7 \%) S$. 
aureus isolates were hemolytic and 41 $(38.3 \%)$ did not produce haemolysis on blood agar. From mastitic milk samples, $62.7 \%$ $(32 / 51)$ isolates were haemolytic followed by from milkers' hands being $61.9 \%(13 / 21)$ and $60.1 \%(21 / 35)$ haemolytic isolates from udder.

All the 107 S. aureus isolates were subjected to PCR amplification for hemolysin genes (hla, hlb and hld) and Panton-Valentine leukocidin (luk-PV) gene using specific primers. The hla and hld genes were detected in all the isolates $(100 \%)$ producing a single amplicon of $534 \mathrm{bp}$ and $111 \mathrm{bp}$ respectively (Figure 1 and 2). The detection rate of $h l b$ gene was $85 \%$ with $88.2 \%$ mastitic milk isolates carrying $h l b$ gene followed by isolates from udder $(82.9 \%)$ and $81 \%$ from milkers' hands (Table 3). The present investigation detected very low prevalence of $l u k$-PV gene in only $21(19.6 \%)$ isolates yielding amplicon of 433 bp while $80.4 \%$ isolates were negative for it. Highest prevalence of luk-PV gene was recorded in isolates from udder 15/35 (42.9\%) followed by isolates from milkers' hands $(14.3 \%)$ and only $5.9 \%$ isolates from mastitic milk were positive for it.

The prevalence of adherence associated genes, clfA, clfB, fnbA and $f n b B$ was $100 \%, 94.4 \%$, $63.6 \%$ and $44.9 \%$ respectively. Higher frequency of clfB gene in mastitic milk isolates (96.07\%), fnbA gene in milkers' hands isolates $(66.7 \%)$ and $f n b B$ gene in $48.6 \%$ udder isolates was recorded. While the betalactamase activity was exhibited by 78 $(72.9 \%)$ isolates but $100 \%$ isolates were positive for blaZ gene (Figure 3). Highest beta lactamase activity was recorded among mastitic milk isolates $(80.4 \%)$ while more than $60 \%$ isolates from udder and milkers' hands showed this activity.

The present study revealed a high prevalence of bovine mastitis due to $S$. aureus in different farms and greater frequency of isolation of $S$. aureus from mastitic milk, udder surfaces and close human contacts. This also suggests the lack of proper management practices of maintaining animal health as well hygiene of the farm and farm workers in arid and semi arid regions of India. The pathogenicity of $S$. aureus is due to the presence of different virulence factors leading to invasion, colonization and infection of host (Soares et al., 2017) and diversity in these virulence factors produced by $S$. aureus strains isolated from bovine mastitis has been reported (Capurro et al., 2010).

Staphylococcal haemolysins are identified as important virulence factors that contribute for bacterial invasion and to escape from the host immune response. In our study, most of $S$. aureus strains showed haemolytic activity on blood agar which is consistent with the results obtained by other authors (Capurro et al., 2010; Kot et al., 2013). The higher prevalence of partial $(\beta)$ hemolysis in $S$. aureus strains observed in present study is similar to the findings of Islam et al., (2007) and Yadav et al., (2015a) who reported $89.3 \%$ and $62.5 \%$ of $S$. aureus strains of bovine mastitic origin to produce incomplete hemolysis. Some workers have reported a higher prevalence of complete or alpha hemolysis in $S$. aureus isolates from various sources (Wang et al., 2011; Younis et al., 2017) which is contrary to present findings. The variations recorded in hemolysis pattern of $S$. aureus isolates from various sources in present or previous studies indicate diversity among isolates with regards to hemolysis property.

By PCR amplification of the genes encoding hemolysins of $S$. aureus with specific primers it could be observed that hla and hld genes were present in all isolates while $85 \%$ isolates were positive for $h l b$ gene. In the present study $91(85 \%)$ isolates were positive for all the three hemolysin genes hla, hlb and hld and 16 isolates did not carry $h l b$ gene but were 
positive for hla and $h l d$ genes. Of these $16 \mathrm{hlb}$ negative isolates, 10 were phenotypically ahaemolytic on sheep blood agar while remaining six was found to be of haemolytic phenotype. This may be due to expression of $\alpha$ or $\delta$ toxins which either alone or synergistically produced hemolysis on blood agar plate. Out of 41 phenotypically ahaemolytic strains, 10 did not carry hlb gene but were positive for hla and hld genes while the remaining 31 isolates were found to carry $h l a, h l b$ and hld genes. This may be due to either silencing of $h l a$ and $h l b$ genes or these genes are not expressed resulting in haemolytic phenotypes. Hence, a little association was observed between hemolytic genotypes and their phenotypic expression. This is similar to the findings of Wang et al., (2011) and Ariyanti et al., (2011) who concluded that the hemolysin genotypes of $S$. aureus and their phenotypic expression do not correlate well. However, Younis et al., (2017) recorded prevalence of hla genes (90.90\%) and $h l b(85.45 \%)$ gene which correlated with their phenotypic hemolytic activity on blood agar plates which is in contrast to present findings.

In the present investigation the prevalence of $h l b$ gene recorded was higher in bovine strains $(86 \%)$ than human strains $(81 \%)$. Likewise, Delgado et al., (2011) observed hlb gene more common in bovine isolates $(80 \%)$ than in human isolates (20\%). In contrast Moraveji et al., (2014) found the $h l b$ gene in $3(15 \%)$ out of 20 isolates collected from bovines and 8 $(40 \%)$ out of 20 isolates collected from humans. The hlb gene present in S. aureus isolates of human origin (55\%), bovine origin (16\%) and from food sources (18\%) was also reported by Salasia et al., (2011) contrary to present observation. Some workers reported higher percentage of isolates with $h l b$ gene than hla gene (Yang et al., 2015; Wang et al., 2016). Although the presence of luk-PV genes in $S$. aureus isolates from bovine mastitis is still insufficiently explored but similar low prevalence of luk-PV gene has also been reported by other workers from bovine mastitis i.e. $2.7 \%$ by Yang et al., (2015), 7.1\% by Awad et al., (2017) and $24.8 \%$ by Hoque $e t$ al., (2018). In contrast, a higher prevalence (65.6\%) of luk-PV gene was observed by ElSayed et al., (2015) in S. aureus isolates from clinical mastitis in cattle and buffaloes. In the present study $21 \%$ bovine strains were positive for luk-PV gene as compared to $14.3 \%$ of human strains which is contrary to the study of Pajic et al., (2014) who recorded luk-PV gene in $6.67 \%$ and $63.63 \%$ of bovine and human isolates of $S$. aureus, respectively.

Regarding the occurrence of genes encoding for $S$. aureus surface proteins involved in adhesion, results obtained in this study have shown similarities and few differences with previous research. The clfA gene was detected in $100 \%$ of the isolates, which is similar to findings of Felipe et al., (2017) and Baloch et al., (2018). Klein et al., (2012) detected 91.8\% and $\mathrm{Xu}$ et al., (2015) found $85.7 \%$ clf $\mathrm{B}$ positive strains from bovine mastitis similar to present study while Felipe et al., (2017) and Zhang et al., (2018) detected clfB gene in $100 \%$ isolates. As compared to present study, a lower prevalence of $c l f \mathrm{~A}$ and $c l f \mathrm{~B}$ genes was reported by Memon et al., (2013), He et al., (2014) and de Almeida et al., (2017). The present study revealed single amplicon of 1000 bp for clfA gene while polymorphic band patterns viz. 950 (3.7\%), 1000 (70.0\%) and $1100 \mathrm{bp}(20.5 \%)$ were observed by Kumar et al., (2011). Further Reinoso et al., (2008), Karahan et al., (2011) and Yadav et al., (2015b) observed two different amplicons of 900 and 1000bp sizes showing polymorphism. The present investigation revealed presence of fibronectin binding proteins, fnbA (63.6\%) and $f n b \mathrm{~B}(44.9 \%)$, in $S$. aureus isolates which play important role in adherence to bovine mammary gland cells leading to infectious mastitis. 
Table.1 Nucleotide sequences used as primers

\begin{tabular}{|c|c|c|c|c|c|}
\hline $\begin{array}{l}\text { S. } \\
\text { No }\end{array}$ & Gene & Primer sequence $\left(5^{\prime}\right.$ to $\left.3^{\prime}\right)$ & $\begin{array}{c}\text { Primer } \\
\text { concentration }\end{array}$ & $\begin{array}{l}\text { Amplicon } \\
\text { size }\end{array}$ & Reference \\
\hline \multirow[t]{2}{*}{1.} & \multirow[t]{2}{*}{ hla } & $\begin{array}{c}\text { F-5' GGT TTA GCC TGG } \\
\text { CCT TC }{ }^{\prime}\end{array}$ & $4 \mathrm{pM} / \mu \mathrm{l}$ & \multirow[t]{2}{*}{$534 \mathrm{bp}$} & \multirow[t]{2}{*}{$\begin{array}{l}\text { Booth et al., } \\
\quad(2001)\end{array}$} \\
\hline & & $\begin{array}{l}\text { R-5' CAT CAC GAA CTC } \\
\text { GTT CG 3' }\end{array}$ & $4 \mathrm{pM} / \mu \mathrm{l}$ & & \\
\hline \multirow[t]{2}{*}{2.} & \multirow[t]{2}{*}{$h l b$} & $\begin{array}{c}\text { F-5' GCC AAA GCC GAA } \\
\text { TCT AAG 3' }\end{array}$ & $4 \mathrm{pM} / \mu \mathrm{l}$ & \multirow[t]{2}{*}{$833 \mathrm{bp}$} & \multirow[t]{2}{*}{$\begin{array}{l}\text { Booth et al. } \\
\quad(2001)\end{array}$} \\
\hline & & $\begin{array}{c}\text { R-5' CGC ATA TAC ATC } \\
\text { CCA TGG C 3' }\end{array}$ & $4 \mathrm{pM} / \mu \mathrm{l}$ & & \\
\hline \multirow[t]{2}{*}{3.} & \multirow[t]{2}{*}{ hld } & $\begin{array}{c}\text { F-5'- AAG AAT TTT TAT } \\
\text { CTT AAT TAA GGA AGG } \\
\text { AGT G-3' }\end{array}$ & $2 \mathrm{pM} / \mu \mathrm{l}$ & \multirow[t]{2}{*}{$111 \mathrm{bp}$} & \multirow[t]{2}{*}{$\begin{array}{l}\text { Jarraud et al. } \\
\quad(2002)\end{array}$} \\
\hline & & $\begin{array}{l}\text { R-5'-TTA GTG AAT TTG } \\
\text { TTC ACT GTG TCG A-3' }\end{array}$ & $2 \mathrm{pM} / \mu \mathrm{l}$ & & \\
\hline \multirow[t]{2}{*}{4.} & \multirow[t]{2}{*}{$\begin{array}{l}\text { luk- } \\
P V\end{array}$} & $\begin{array}{c}\text { F-5'- -ATC ATT AGG TAA } \\
\text { AAT GTC TGG ACA TGA } \\
\text { TCC A-3' }\end{array}$ & $2 \mathrm{pM} / \mu \mathrm{l}$ & \multirow[t]{2}{*}{$433 \mathrm{bp}$} & \multirow[t]{2}{*}{$\begin{array}{l}\text { Lina et al. } \\
\text { (1999) }\end{array}$} \\
\hline & & $\begin{array}{c}\text { R-5' -GCA TCA AST GTA } \\
\text { TTG GAT AGC AAA AGC- } \\
3^{\prime} \text {. }\end{array}$ & $2 \mathrm{pM} / \mu \mathrm{l}$ & & \\
\hline \multirow[t]{2}{*}{5.} & \multirow[t]{2}{*}{ clfA } & $\begin{array}{c}\text { F-5'-GGC TTC AGT GCT } \\
\text { TGT AGG-3' }\end{array}$ & $4 \mathrm{pM} / \mu \mathrm{l}$ & \multirow[t]{2}{*}{$1000 \mathrm{bp}$} & \multirow[t]{2}{*}{$\begin{array}{l}\text { Stephan } e t \\
\text { al. }(2001)\end{array}$} \\
\hline & & $\begin{array}{l}\text { R-5'-TTT TCA GGG TCA } \\
\text { ATA TAA GC-3' }\end{array}$ & $4 \mathrm{pM} / \mu \mathrm{l}$ & & \\
\hline \multirow[t]{2}{*}{6.} & \multirow[t]{2}{*}{ clfB } & $\begin{array}{l}\text { F-5'-ACA TCA GTA ATA } \\
\text { GTA GGG GGC AAC-3' }\end{array}$ & $2 \mathrm{pM} / \mu \mathrm{l}$ & \multirow[t]{2}{*}{$205 b p$} & \multirow[t]{2}{*}{$\begin{array}{l}\text { Tristan et al. } \\
\quad(2003)\end{array}$} \\
\hline & & $\begin{array}{l}\text { R-5'-TTC GCA CTG TTT } \\
\text { GTG TTT GCA C-3' }\end{array}$ & $2 \mathrm{pM} / \mu \mathrm{l}$ & & \\
\hline \multirow[t]{2}{*}{7.} & \multirow[t]{2}{*}{$f n b A$} & $\begin{array}{l}\text { F-5'-GCG GAG ATC AAA } \\
\text { GAC AA-3' }\end{array}$ & $4 \mathrm{pM} / \mu \mathrm{l}$ & \multirow[t]{2}{*}{$1279 \mathrm{bp}$} & \multirow[t]{2}{*}{$\begin{array}{l}\text { Nashev et al. } \\
\quad(2004)\end{array}$} \\
\hline & & $\begin{array}{l}\text { R-5'-CCA TCT ATA GCT } \\
\text { GTG TGG-3' }\end{array}$ & $4 \mathrm{pM} / \mu \mathrm{l}$ & & \\
\hline \multirow[t]{2}{*}{8.} & \multirow[t]{2}{*}{$f n b B$} & $\begin{array}{c}\text { F-5'-GGA GAA GGA ATT } \\
\text { AAG GCG-3' }\end{array}$ & $4 \mathrm{pM} / \mu \mathrm{l}$ & \multirow[t]{2}{*}{$812 \mathrm{bp}$} & \multirow[t]{2}{*}{$\begin{array}{l}\text { Nashev et al } \\
\quad(2004)\end{array}$} \\
\hline & & $\begin{array}{l}\text { R-5'-GCC GTC GCC TTG } \\
\text { AGC GT-3' }\end{array}$ & $4 \mathrm{pM} / \mu \mathrm{l}$ & & \\
\hline \multirow[t]{2}{*}{9.} & \multirow[t]{2}{*}{ blaZ } & $\begin{array}{c}\text { F-5'-AAG AGA TTT GCC } \\
\text { TAT GCT TC-3' }\end{array}$ & $4 \mathrm{pM} / \mu \mathrm{l}$ & \multirow[t]{2}{*}{$517 \mathrm{bp}$} & \multirow[t]{2}{*}{$\begin{array}{l}\text { Sawant et al. } \\
\quad \text { (2009) }\end{array}$} \\
\hline & & $\begin{array}{c}\text { R-5'-GCT TGA CCA CTT } \\
\text { TTA TCA GC-3' }\end{array}$ & $4 \mathrm{pM} / \mu \mathrm{l}$ & & \\
\hline
\end{tabular}


Table.2 Cycling conditions used in PCR

\begin{tabular}{|c|c|c|c|c|c|c|c|}
\hline $\begin{array}{c}\text { PCR } \\
\text { Type }\end{array}$ & Gene & $\begin{array}{c}\text { Primary } \\
\text { denaturat } \\
\text { ion }\end{array}$ & $\begin{array}{c}\text { Secondary } \\
\text { denaturation }\end{array}$ & $\begin{array}{c}\text { Anneal } \\
\text { ing }\end{array}$ & Extension & $\begin{array}{c}\text { No. of } \\
\text { cycles }\end{array}$ & $\begin{array}{c}\text { Final } \\
\text { extension }\end{array}$ \\
\hline $\begin{array}{c}\text { Multiple } \\
\text { x Set A }\end{array}$ & $\begin{array}{c}b l a Z, f n b A \\
f n b B\end{array}$ & $\begin{array}{c}94^{\circ} \mathrm{C} \\
5 \mathrm{~min}\end{array}$ & $94^{\circ} \mathrm{C}$ & $50^{\circ} \mathrm{C}$ & $72^{\circ} \mathrm{C}$ & 30 & $72^{\circ} \mathrm{C}$ \\
\hline $\begin{array}{c}\text { Multiple } \\
\text { x Set B }\end{array}$ & $l u k-\mathrm{PV}$ & $94^{\circ} \mathrm{C}$ & $94^{\circ} \mathrm{C}$ & $55^{\circ} \mathrm{C}$ & $72^{\circ} \mathrm{C}$ & 30 & $72^{\circ} \mathrm{C}$ \\
& $h l d f B$ & $5 \mathrm{~min}$ & $1 \mathrm{~min}$ & $1 \mathrm{~min}$ & $1 \mathrm{~min}$ & & $7 \mathrm{~min}$ \\
\hline $\begin{array}{c}\text { Multiple } \\
\text { x Set C }\end{array}$ & $\begin{array}{c}c l f A, h l a, \\
h l b\end{array}$ & $94^{\circ} \mathrm{C}$ & $94^{\circ} \mathrm{C}$ & $50^{\circ} \mathrm{C}$ & $72^{\circ} \mathrm{C}$ & 30 & $72^{\circ} \mathrm{C}$ \\
\hline
\end{tabular}

Fig.1 PCR amplicons of $c l f A, h l a, h l b$ genes of $S$. aureus isolates using DNA ladder (M) of IKbp

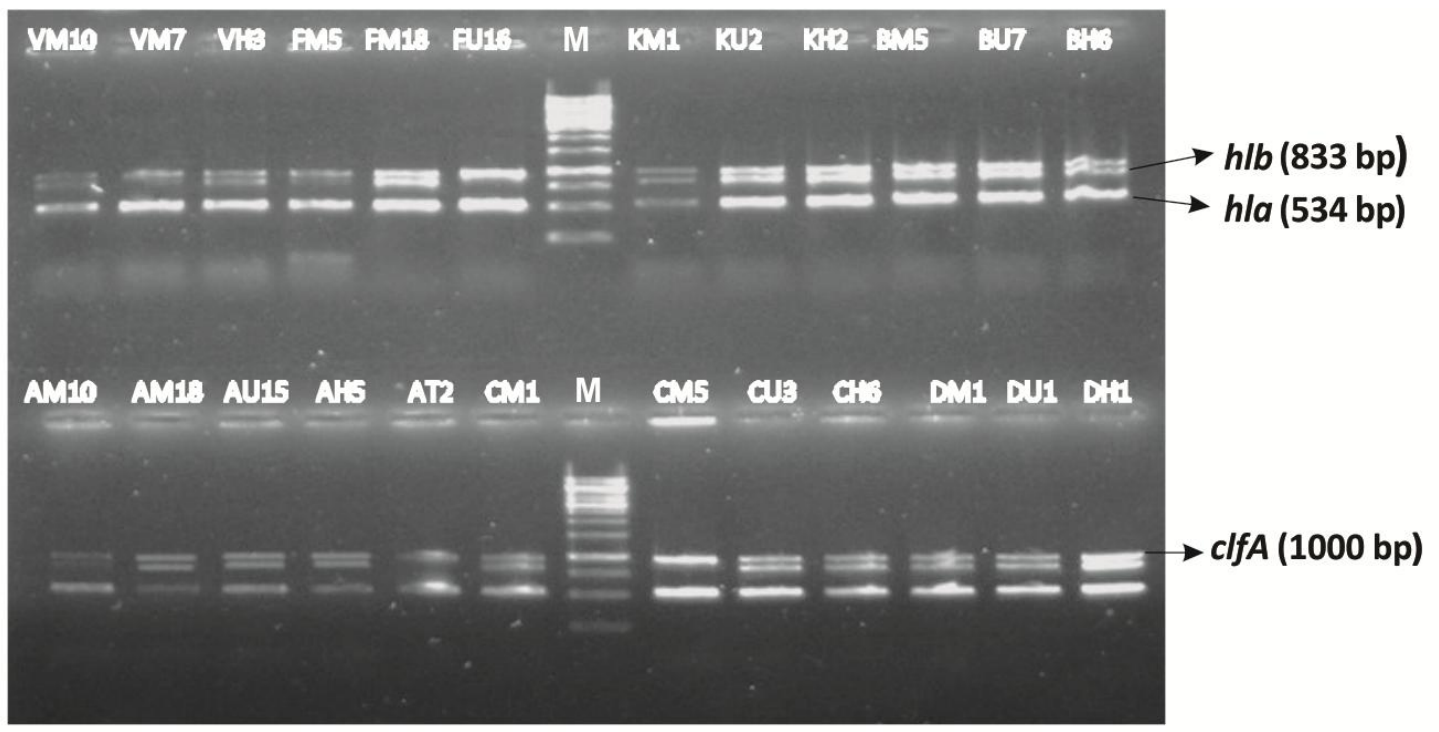

Fig.2 PCR amplicons of $c l f B, h l d$, luk-PV genes of $S$. aureus isolates using DNA ladder (M) of I00 bp

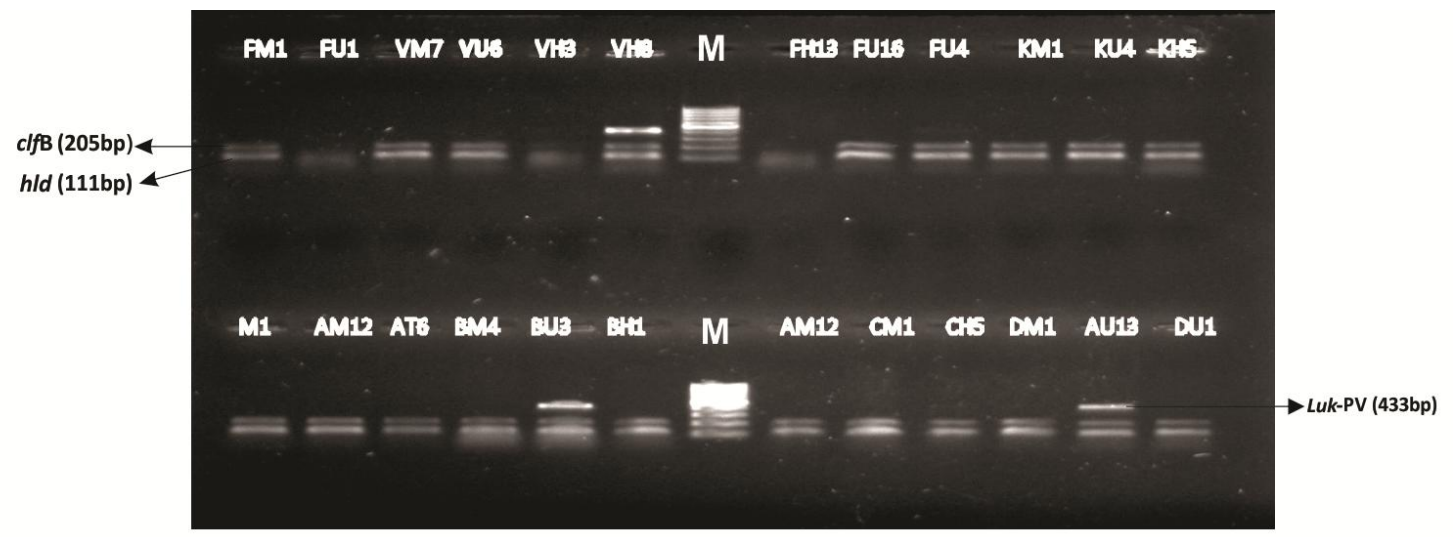


Fig.3 PCR amplicons of $f n b A, f n b B$, blaZ genes of $S$. aureus isolates using DNA ladder (M) of $500 \mathrm{bp}$

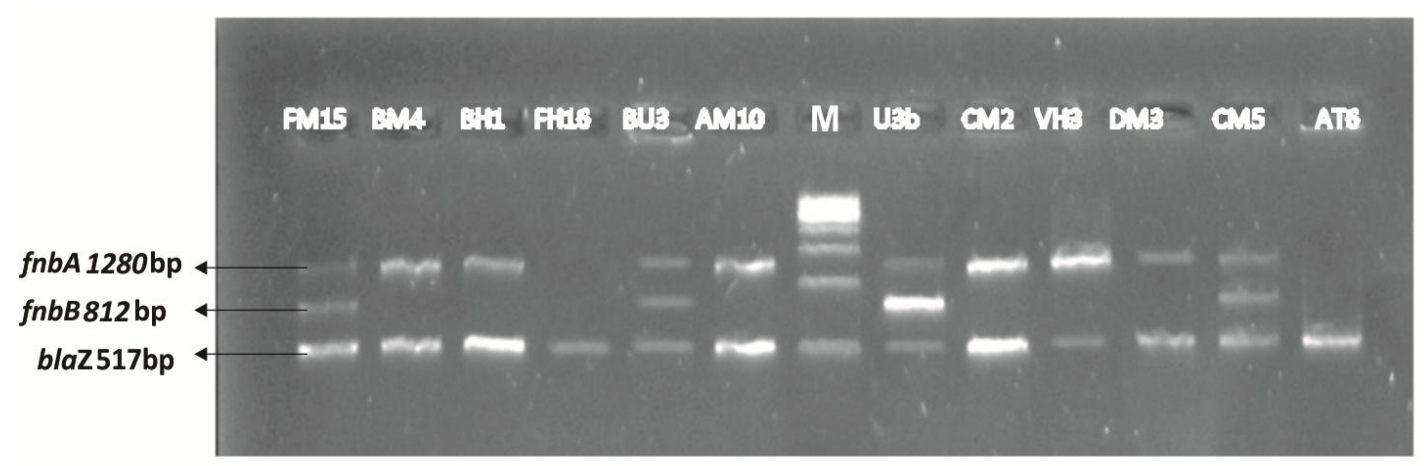

Table.3 Prevalence of different virulence factors in S. aureus isolates

\begin{tabular}{|c|c|c|c|c|c|c|c|c|c|c|}
\hline \multirow[t]{2}{*}{ Source of sample } & \multicolumn{10}{|c|}{ Prevalence (\%) } \\
\hline & $f n b A$ & $f n b B$ & clfA & clfB & hla & $h l b$ & hld & $\begin{array}{c}L u K- \\
P V\end{array}$ & $\begin{array}{c}\beta- \\
\text { lactamase } \\
\text { production }\end{array}$ & blaZ \\
\hline $\begin{array}{l}\text { Mastitic milk } \\
\quad(n-51)\end{array}$ & $\begin{array}{c}32 \\
(62.7)\end{array}$ & $\begin{array}{c}21 \\
(41.2)\end{array}$ & $\begin{array}{c}51 \\
(100)\end{array}$ & $\begin{array}{c}49 \\
(96.1)\end{array}$ & $\begin{array}{c}51 \\
(100)\end{array}$ & $\begin{array}{c}45 \\
(88.2)\end{array}$ & $\begin{array}{c}51 \\
(100)\end{array}$ & $\begin{array}{c}03 \\
(5.9)\end{array}$ & $\begin{array}{c}41 \\
(80.4)\end{array}$ & $\begin{array}{c}51 \\
(100)\end{array}$ \\
\hline $\begin{array}{c}\text { Udder swabs } \\
\quad(\mathbf{n}-35)\end{array}$ & $\begin{array}{c}22 \\
(62.9)\end{array}$ & $\begin{array}{c}17 \\
(48.6)\end{array}$ & $\begin{array}{c}35 \\
(100)\end{array}$ & $\begin{array}{c}32 \\
(91.4)\end{array}$ & $\begin{array}{c}35 \\
(100)\end{array}$ & $\begin{array}{c}29 \\
(82.9)\end{array}$ & $\begin{array}{c}35 \\
(100)\end{array}$ & $\begin{array}{c}15 \\
(42.9)\end{array}$ & $\begin{array}{c}23 \\
(65.7)\end{array}$ & $\begin{array}{c}35 \\
(100)\end{array}$ \\
\hline $\begin{array}{c}\text { Milkers hands } \\
\text { swabs } \\
(\mathbf{n}-21)\end{array}$ & $\begin{array}{c}14 \\
(66.7)\end{array}$ & $\begin{array}{c}10 \\
(47.6)\end{array}$ & $\begin{array}{c}21 \\
(100)\end{array}$ & $\begin{array}{c}20 \\
(95.2)\end{array}$ & $\begin{array}{c}21 \\
(100)\end{array}$ & $\begin{array}{c}17 \\
(81)\end{array}$ & $\begin{array}{c}21 \\
(100)\end{array}$ & $\begin{array}{c}03 \\
(14.3)\end{array}$ & $\begin{array}{c}14 \\
(66.7)\end{array}$ & $\begin{array}{c}21 \\
(100)\end{array}$ \\
\hline Total $n=107$ & $\begin{array}{c}68 \\
(63.6)\end{array}$ & $\begin{array}{c}48 \\
(44.9)\end{array}$ & $\begin{array}{c}107 \\
(100)\end{array}$ & $\begin{array}{c}101 \\
(94.4)\end{array}$ & $\begin{array}{c}107 \\
(100)\end{array}$ & $\begin{array}{c}91 \\
(85)\end{array}$ & $\begin{array}{c}107 \\
(100)\end{array}$ & $\begin{array}{c}21 \\
(19.6)\end{array}$ & $\begin{array}{c}78 \\
(72.9)\end{array}$ & $\begin{array}{c}107 \\
(100)\end{array}$ \\
\hline
\end{tabular}

The prevalence of fnbA gene has been reported as high as $100 \%$ in $S$. aureus isolates from intramammary infections by workers from different study areas (Yang et al., 2012; Felipe et al., 2017; Baloch et al., 2018) to as low as $27.3 \%$ by Soares et al., (2017). Further, fnbA gene was not detected in any strain from bovine subclinical mastitis by Memon et al., (2013) and He et al., (2014). As compared to present study a higher percentage of $S$. aureus isolates were detected with $f n b B$ gene by other workers from bovine mastitis i.e. $80 \%$ by Wang et al., (2016) $76.3 \%$ by Felipe et al., (2017); 78.2\% by Soares et al., (2017) and $85 \%$ by Zhang et al., (2018) while none of the investigated $S$. aureus strains harbouring $f n b B$ gene was reported by Yang et al., (2012). These variations have been suggested to depend either on the specific geographic region or, alternatively, on methodological differences. Khoramian et al., (2015) studied 215 S. aureus strains collected from human and dairy cow's infections and reported the prevalence of $f n b \mathrm{~A}$ gene among the bovine isolates significantly higher than those in the human isolates which is contrary to present findings where the prevalence of $f n b \mathrm{~A}$ gene among the human isolates was higher.

Prevalence of penicillin resistance in staphylococci causing animal diseases is most commonly due to the blaZ gene encoding for 
penicillinases (beta lactamase). In contrast to present study, lower beta-lactamase production in $55.9 \%$ and $9 \%$ of the isolates from clinical mastitis was reported by Turutologu et al., (2006) and Capurro et al., (2010) respectively. Bagcigil et al., (2012) identified 78 beta-lactamase positive isolates out of 147 isolates with positive blaZ gene while Marques et al., (2017) reported 100\% beta lactamse producing $S$. aureus isolates from bovine mastitis.

The present study detected blaZ gene in all the isolates which is similar to findings of Yang et al., (2015) who detected blaZ gene in $94.6 \%$ of penicillin resistant $S$. aureus isolates from bovine mastitis cases. Our result of all the isolates carrying blaZ gene but only 78 (72.9\%) isolates exhibiting beta-lactamase activity is in contrast to the results of Robles et al., (2014) who reported that several $S$. aureus isolates from bovine mastitis did not harbor the blaZ gene but phenotypic tests showed beta-lactamase activity. Hence, betalactamase phenotype could be result of expression of more than one gene and more than one mechanism is responsible for betalactam resistance other than the expression of blaZ gene. As reported by Robles et al., (2014) it was observed that PCR detection of blaZ gene had a low association with all phenotypic tests and there could be a strong possibility that beta-lactamase production was herd-dependent.

In conclusion, the high percentage of hemolysin, clf $\mathrm{A}$ and $c l f \mathrm{~B}$ producing strains obtained in this work suggest an important role of these virulence factors in the pathogenesis of bovine mastitis in the farms. The strains showed diversity in the pattern of the virulence gene profiles. The presence of genes and their phenotypic expression did not correlate well in this study. Further the development of resistance towards betalactum antibiotics is of concern in the arid and semiarid regions of India which may pose problems in the treatment of clinical cases. Considerable pathogenic strains were obtained from milk handlers which may be either transmitted to or contracted from infected cattle which require further research. This also indicates the requirement to educate the farmers towards mastitis management.

\section{Acknowledgment}

The authors are thankful to the Dean, College of Veterinary and Animal Science, Rajasthan University of Veterinary and Animal Sciences, Bikaner for financial support and the Head, Department of Veterinary Microbiology and Biotechnology for providing laboratory facilities for this research.

\section{References}

Ariyanti, D., S.I.O. Salasia, Tato, S. 2011. Characterization of haemolysin of Staphylococcus aureus isolated from food of animal origin. Indones $\mathrm{J}$ Biotechnol. 6 (1): 32-37.

Awad, A., H. Ramadan, S.M. Nasr, A. Ateya, Atwa, S. 2017. Genetic characterization, antimicrobial resistance patterns and virulence determinants of Staphylococcus aureus Isolated form bovine mastitis. Pak J Biol Sci. 20(6): 298-305.

Bagcigil, A.F., S. Taponen, J. Koort, B. Bengtsson, A.L. Myllyniemi, Pyörälä, S. 2012. Genetic basis of penicillin resistance of S. aureus isolated in bovine mastitis. Acta Vet Scand. 54 (69): 1-7.

Baloch, Z., W. Wang, X. Lin, J. Xu, Tao, J., et al., 2018. Prevalence and characterization of Staphylococcus aureus cultured from raw milk taken from dairy cows with mastitis in Beijing, China. Front Microbiol. 10.3389/ fmicb.2018.01123

Benić, M., B. Habrun, Kompes, G. 2012. Clinical and epidemiological aspects of cow mastitis caused by Staphylococcus 
aureus and its methicillin-resistant strains. J Croat Acad Sci Arts: Med Sci. 37:113-122.

Bhati, T., K. Gaurav, V. Khichar, Kataria, A.K. 2018. Prevalence of Staphylococcus aureus isolated from mastitic milk, udder surfaces and milkers' hands from different farms in Bikaner, Rajasthan. J Anim Res. 8 (5): 867-872.

Booth, M.C., L.M. Pence, P. Mahasreshti, M. Callegan, Gilmore, M. 2001. Clonal associations among Staphylococcus aureus isolates from various sites of infections. Infect Immun. 69 (1): 345352.

Brakstad, O.G., K. Aasbakk, Maeland, J.A. 1992. Detection of Staphylococcus aureus by polymerase chain reaction amplification of the nuc gene. J Clin Microbiol. 30 (7): 1654-1660.

Capurro, A., A. Aspán, K. Artursson, Waller, K. P. 2010. Genotypic variation among Staphylococcus aureus isolates from cases of clinical mastitis in Swedish dairy cows. Vet J. 185 (2): 188-192.

Cirkovic, I., M. Sorum, D. Radenkovic, M. Svabic Vlahovic, Larsen, A. R. 2012. National surveillance reveals the first findings of Panton Valentine leukocidin positive methicillin-resistant Staphylococcus aureus in Serbia. J Med Microbiol. 62: 342-344.

da Silva, E. R., J.U.D. Boechat, da Silva, N. 2005. Coagulase gene polymorphism of Staphylococcus aureus isolated from goat mastitis in Brazilian dairy herds. Lett Appl Microbiol. 42 (1):30-34.

de Almeida, C. C., L.J.L. Pizauro, D.R.J. Oswaldo, Pizauro, J. M. 2017. Identification and production of biofilm by Staphylococcus aureus isolated from buffalo milk and milking environment. Afr J Microbiol Res. 11(4): 132-140.

Delgado, S., P. Garcia, L. Fernandez, E. Jimenez, Banos, M. R., et al., 2011. Characterization of Staphylococcus aureus strains involved in human and bovine mastitis. FEMS Immunol Med Microbiol. 62 (2): 225-
235.

El-Sayed, M. S., A. M. El-Bagoury, Dawoud, M.A. 2015. Phenotypic and genotypic detection of virulence factors of Staphylococcus aureus isolated from clinical and subclinical mastitis in cattle and water buffaloes from different farms of Sadat City in Egypt. Vet World. 8(9):1051-1058.

Felipe, V., C. A. Morgante, P.S. Somale, F. Varroni, Zingaretti, M.L., et al., 2017. Evaluation of the biofilm forming ability and its associated genes in Staphylococcus species isolates from bovine mastitis in Argentinean dairy farms. Microb Pathog. 104: 278-286.

Gandhale, D., R. Kolhe, S. Nalband, P. Deshpande, Jagtap, U. et al., 2017. Molecular types and antimicrobial resistance profile of Staphylococcus aureus isolated from dairy cows and farm environments. Turk J Vet Anim Sci. 41:713-724.

Hanon, B.M. 2017. Molecular Study of some virulence genes in biotype diversity of methicillin resistance Staphylococcus aureus isolated from handling carrier and bovine mastitis. Int J Sci Res. 6 (2):1746-1752.

Haveri, M., A. Roslof, F. Rantala, Pyorala, S. 2007. Virulence genes of bovine Staphylococcus aureus from persistent and non-persistent intramammary infections with different clinical characteristics. J Appl Microbiol. 103 (4): 993-1000.

He, J., A. Wang, G. Liu, J. Gao, T. Ali, Han, B. 2014. Biofilm formation and biofilmassociated genes assay of Staphylococcus aureus isolated from bovine subclinical mastitis in China. Pak Vet J; 34 (4): 508-513.

Higgins, J., A. Loughman, K.P. van Kessel, J.A. van Strijp, Foster, T. J. 2006. Clumping factor A of Staphylococcus aureus inhibits phagocytosis by human polymorphonuclear leucocytes. FEMS Microbiol Lett. 258: 290-296.

Hoque, M. N., Z. C. Das, A.N.M.A. Rahman, 
M.G. Haider, Islam, M.A. 2018. Molecular characterization of Staphylococcus aureus strains in bovine mastitis milk in Bangladesh. Int $\mathrm{J}$ Vet Sci Med. 6(1): 53-60.

Islam, M.I., M.S. Uddin, M.A. Islam, K.H.M.N.H. Nazim, M.T. Rahman, Alam, M.M. 2007. Detection and characterization of coagulase positive Staphylococcus aureus of bovine origin producing enterotoxins and toxic shock syndrome toxin-I. The Bangladesh Veterinary. 24: 27-33.

Jarraud, S., C. Mougel, J. Thioulouse, G. Lina, Meugnier, H., et al., 2002. Relationships between Staphylococcus aureus genetic background, virulence factors, agr groups (alleles), and human disease. Infect Immun. 70 (2): 631-641.

Kaneko, J., and Kamio, Y. 2004. Bacterial twocomponent and hetero-heptameric poreforming cytolytic toxins: structures, pore-forming mechanism, and organization of the genes. Biosci Biotechnol Biochem. 68: 981-1003.

Karahan, M., M. Nuri Aciki, Cetinkaya, B. 2011. Investigation of virulence genes by PCR in Staphylococcus aureus isolates originated from subclinical bovine mastitis in Turkey. Pak Vet J. 31 (3): 249-253.

Khoramian, B., F. Jabalameli, A. NiasariNaslaji, M. Taherikalani, Emaneini, M. 2015. Comparison of virulence factors and biofilm formation among Staphylococcus aureus strains isolated from human and bovine infections. Microb Pathog. 88: 73-77.

Klein, R.C., M.H.F. Klein, M.A.V.P. Brito, L.G. Fietto, Ribon, Ade O. B. 2012. Staphylococcus aureus of bovine origin: Genetic diversity, prevalence and the expression of adhesin-encoding genes. Vet Microbiol. 160(1-2): 183-188.

Kot, B., T. Binek, M. Piechota, K.M. Wolska, E. Zdunek, Patkowska, K. 2013. Virulence factors and ability of Staphylococci from bovine milk and the cowshed environment to biofilm formation. Pol J
Vet Sci. 16(4): 639-645.

Kumar, R., B. R. Yadav, Singh, R. S. 2011. Antibiotic resistance and pathogenicity factors in Staphylococcus aureus isolated from mastitic Sahiwal cattle. J Biosci. 36 (1): 175-188.

Lina, G., Y. Piémont, F. Godail-Gamot, M. Bes, Peter, M.O., et al., 1999. Involvement of Panton - Valentine leukocidin producing Staphylococcus aureus in primary skin infections and pneumonia. Clin Infect Dis. 29, 1128-1132.

Livermore, D. M, and Brown, D.F.J. 2001. Detection of $\beta$-lactamase mediated resistance. J Antimicrob Chemother. 48: 59-64.

Markey, B. K., F. Leonard, M. Archambault, A. Culinane, Maguire, D. In: Clinical Veterinary Microbiology. 2nd Edition 2013; 901 pages. Mosby/Elsevier, Edinburgh, Scotland.

Marques, V. F., C. C. da Motta, B.da.S. Soares, D.ade. Melo, Coelho, Sde.Mde.O et al., 2017. Biofilm production and betalactamic resistance in Brazilian Staphylococcus aureus isolates from bovine mastitis. Braz J Microbiol. 48(1), 118-124.

Memon, J., Y. Yang, J. Kashif, M. Yaqoob, Buriro, R., et al., 2013. Genotypes, virulence factors and antimicrobial resistance genes of Staphylococcus aureus isolated in bovine subclinical mastitis from Eastern China. Pak Vet J. 33 (4): 486-491.

Moraveji, Z., M. Tabatabaei, S.H. Aski, Khoshbakht, R. 2014. Characterization of hemolysins of Staphylococcus strains isolated from human and bovine, southern Iran. Iran J Vet Res. 15 (4): 326-330.

Nachimuttu, K., P. Ramadas, V. Thiagarajan, G.D. Raj, Kumanam, K. Laboratory manual on Polymerase chain reaction based methods for diagnosis. A workshop sponsored by NATP at Tamil Nadu Veterinary and Animal Science University from 21.02.2001 to 07.03.2001 pp 5-13. 
Nashev, D., K. Toshkova, S.I. Salasia, A.A. Hassan, C. Lammler, Zschock, M. 2004. Distribution of virulence genes of Staphylococcus aureus isolated from stable nasal carriers. FEMS Microbiol Lett. 233:45-52.

Ni Eidhin, D., S. Perkins, P. Francoi, P. Vaudaux, M. Hook, Foster, T. J. 1998. Clumping factor B $(C l f B)$, a new surface-located fibrinogen-binding adhesin of Staphylococcus aureus. Mol Microbiol. 30: 245-257.

Pajić, M.J., Z.B. Rašić, B.M. Velebit, S.F. Boboš, Mihajlović-Ukropina, M.M., et $a l$. 2014. The prevalence of mecA, $m e c \mathrm{C}$ and PVL genes in Staphylococcus aureus of bovine and human origin. Vet arhiv. 84 (3): 205-214.

Park, P.W., T. J. Foster, E. Nishi, S. J. Duncan, M. Klagsbrun, Chen, Y. 2004. Activation of syndecan-1 ectodomain shedding by Staphylococcus aureus $\alpha$ toxin and $\beta$-toxin. $\mathbf{J}$ Biol Chem. 279(1):251-258.

Pitkala, A., L. Salmikivi, P. Bredbacka, A. L. Myllyniemi, Koskinen, M. T. 2007. Comparison of tests for detection of beta-lactamase-producing staphylococci. J Clin Microbiol. 45:2031-2033.

Quinn, P.J., M. E. Carter, B. Markey, Carter, G. R. 2000. Staphylococcus species. In: Clinical Veterinary Microbiology, Mosby, Edinburgh; (pp.118-126).

Reinoso,,E.B., A. El-Sayed, C. Lämmler, C. Bogni, Zschöck, M. 2008. Genotyping of Staphylococcus aureus isolated from humans, bovine subclinical mastitis and food samples in Argentina. Microbiol Res. 163 (3): 314-322.

Robles, B. F., D. B. Nóbrega, F. F. Guimarães, G. G. Wanderley, Langoni, H. 2014. Beta-lactamase detection in Staphylococcus aureus and coagulasenegative Staphylococcus isolated from bovine mastitis. Pesqui Vet Bras. 34(4):325-328.

Salasia, S.I.O., S. Tato, N. Sugiyno, D. Ariyanti, Prabawati, F. 2011. Genotypic characterization of Staphylococcus aureus isolated from bovines, humans, and food in Indonesia. J Vet Sci. 12 (4): 353-361.

Sambrook, J., E. F. Fritsch, Maniatis, T. 1989. Purification of DNA. In: Molecular cloning:A Laboratory Manual. $2^{\text {nd }}$ edn. Cold-Spring Harbor Laboratory,.ColdSpring Harbor, New York.

Sawant, A.A., B.E. Gillespie, Oliver, S.P. 2009. Antimicrobial susceptibility of coagulase-negative Staphylococcus species isolated from bovine milk. Vet Microbiol. 134: 73-81.

Soares, B.S., D.A. Melo, C.C. Motta, V.F. Marques, Barreto, N.B., et al., 2017. Characterization of virulence and antibiotic profile and agr typing of Staphylococcus aureus from milk of subclinical mastitis bovine in State of Rio de Janeiro. Arq Bras Med Vet Zoo. 69 (4): 843-850.

Stephan, R., C. Annemuller, A. Hassan, Lammler, C. 2001. Characterization of enterotoxigenic Staphylococcus aureus strains isolated from bovine mastitis in north-east Switzerland. Vet Microbiol. 78 (4): 373-382.

Straub, J.A., C. Hertel, Hammesl W.P. 1999. A 23S rRNA target polymerase chain reaction based system for detection of Staphylococcus aureus in meat starter cultures and dairy products. J Food Prot. 62 (10): 1150-1156.

Tristan, A., L. Ying, M. Bes, J. Etienne, F. Vandenesch, Lina, G. 2003. Use of multiplex PCR to identify Staphylococcus aureus adhesins involved in human hematogenous infections. J Clin Microbiol. 41: 44654467.

Turutoglu, H., S. Ercelik, Ozturk, D. 2006. Antibiotic resistance of Staphylococcus aureus and coagulase-negative staphylococci isolated from bovine mastitis. B Vet I Pulawy.; 50: 41-45.

Wang, F., Y. Hongjun, H. Hong-bin, W. Changfa, Yundong, G., et al., 2011.Study on the hemolysis phenotype and the genotype distribution of 
Staphylococcus aureus caused bovine mastitis in Shandong dairy farms. Int $\mathbf{J}$ Appl Res Vet M. 9 (4): 416-421.

Wang, D., L. Zhang, X. Zhou, Y. He, Yong, C., et al., 2016. Antimicrobial susceptibility, virulence genes, and randomly amplified polymorphic DNA analysis of Staphylococcus aureus recovered from bovine mastitis in Ningxia, China. J Dairy Sci. 99 (12): 9560- 9569.

Wann, E. R., S. Gurusiddappa, Hook, M. 2000. The fibronectin binding MSCRAMM FnbpA of Staphylococcus aureus is a bifunctional protein that also binds to fibrinogen. J Biol Chem. 275: 1386313871

Xu, J., X. Tan, X. Zhang, X. Xia, Sun, H. 2015. The diversities of staphylococcal species, virulence and antibiotic resistance genes in the subclinical mastitis milk from a single Chinese cow herd. Microb Pathog. 88: 29-38.

Yadav, R., S. K. Sharma, J. Yadav, T. Bhati, Kataria, A. K. 2015a. Phenotypic and genotypic haemolysis properties of Staphylococcus aureus obtained from mastitic milk of cattle and buffalo with clinical mastitis. J Pure Appl Microbiol. 9 (1): 349-355.

Yadav, R., S. K. Sharma, J. Yadav, Kataria, A. K. 2015b. Typing of Staphylococcus aureus obtained from mastitic milk of cattle and buffalo on the basis of two virulence-associated genes (spa and clfA). Vet World. 8 (3): 398-402.

Yang, F., Q. Wang, X. Wang, L. Wang, Xiao, M. et al., 2015. Prevalence of blaZ gene and other virulence genes in penicillinresistant Staphylococcus aureus isolated from bovine mastitis cases in Gansu, China. Turk J Vet Anim Sci. 39: 634636.

Yang, F.L., X.S. Li, X.W. Liang, X.F. Zhang, G.S. Qin, Yang, B. Z. 2012. Detection of virulence-associated genes in Staphylococcus aureus isolated from bovine clinical mastitis milk samples in Guangxi. Trop Anim Health Pro. 44 (8): 1821-1826.

Younis, G., A. Awad, Shabana, B. 2017. Phenotypic and molecular characterization hemolysins of Staphylococcus aureus isolated from mastitic cow's milk in Egypt. Int J Agric Sci Vet Med. 5 (4): 83-93.

Zhang, L., J. Gao, H.W. Barkema, T. Ali, Liu, G., et al., 2018. Virulence gene profiles: alpha-hemolysin and clonal diversity in Staphylococcus aureus isolates from bovine clinical mastitis in China. BMC Vet Res. 14(1):63. doi: 10.1186/s12917018-1374-7.

\section{How to cite this article:}

Taruna Bhati, Kumar Gaurav, Sunita Choudhary, Diwakar and Anil Kumar Kataria. 2019. Molecular Detection of Some Virulence Genes of Staphylococcus aureus Isolates Associated with Bovine Mastitis in Arid and Semi-Arid Regions of India. Int.J.Curr.Microbiol.App.Sci. 8(11): 2350-2362. doi: https://doi.org/10.20546/ijcmas.2019.811.272 